\section{Cureus}

Received 06/09/2018

Review began 07/02/2018

Review ended 07/10/2018

Published 07/13/2018

C Copyright 2018

Mir et al. This is an open access article distributed under the terms of the Creative Commons Attribution License CC-BY 3.0., which permits unrestricted use, distribution, and reproduction in any medium, provided the original author and source are credited.

\title{
Malignant Hypertension in Association with Low Estrogen Dose Oral Contraceptives: Case Report and Review of Literature
}

\author{
Danial Mir ${ }^{1}$, Arash Ardabilygazir ${ }^{1}$, Sonia Afshariyamchlou ${ }^{2}$, Issac Sachmechi ${ }^{3}$ \\ 1. Medicine, Icahn School of Medicine at Mount Sinai/Queens Hospital Center, New York, USA 2. Internal \\ Medicine/Endocrinology, Icahn School of Medicine at Mount Sinai/Queens Hospital Center, Jamaica, USA \\ 3. Internal Medicine, Icahn School of Medicine at Mount Sinai/Queens Hospital Center, New York, USA
}

$\square$ Corresponding author: Danial Mir, danialmir77@gmail.com

Disclosures can be found in Additional Information at the end of the article

\section{Abstract}

Malignant hypertension ( $\mathrm{MH}$ ) has been described in association with high-dose (50 - $100 \mathrm{mcg}$ ) estrogen oral contraceptive pills (OCPs). Although the rise in blood pressure (BP) is usually mild, some women will have a more significant increase in BP, and hypertensive emergencies may very rarely occur. We present a 21 -year-old Caucasian female with a past medical history of fibromyalgia and family history of hypertension (both grandparents) who was admitted with a three-day history of headache and blurring of vision in her left eye with a BP of 210/150. Her medications, which were continued on admission, included tramadol, $100 \mathrm{mg}$ twice daily (bid), and low-dose estrogen OCP. During the hospital course, she received different antihypertensive medications and her hypertension was controlled. A diagnosis of MH due to OCP was made. All antihypertensive medications were stopped, except metoprolol, and the patient was discharged home on metoprolol with a BP of $107 / 55 \mathrm{mmHg}$. On follow-up in the medical clinic three months later, her visual disturbances had completely resolved and her BP was 98/56 mmHg.

One-third of patients aged 15 - 44 years old who develop MH are likely to be on high-dose estrogen OCP. As far as we know, our case is the third documented case of MH occurring in patients on low-dose estrogen OCP. Chronic use of oral contraceptives will slightly increase the systemic BP in most women. It is advisable to avoid OCP in high-risk patients and do regular BP checks on patients on OCP. In patients presenting with hypertension or MH while on OCP, the OCP should be discontinued.

Categories: Endocrinology/Diabetes/Metabolism, Internal Medicine, Obstetrics/Gynecology Keywords: malignant hypertension, high blood pressure and oral contraceptive pills, high-dose estrogen and blood pressure, oral contraceptive pills (ocp)

\section{Introduction}

For millions of women, oral contraceptive pills (OCPs) are an effective way to prevent an unwanted pregnancy, get irregular periods back on track, and help clear up problems due to hormonal shifts, such as acne. For the most part, birth control pills are safe and have merely minor potential side effects. However, OCPs may be associated with an increased risk of myocardial infarction (MI). Because MI is an extremely rare event in otherwise healthy women of reproductive age, even a doubling of the risk would result in an extremely low attributable risk [1]. An increase in the risk of venous thromboembolic (VTE) disease is seen with both high 
and low-dose estrogen OCP preparations. Although the reduction in steroid content of OCPs has improved the safety and side effect profile of the pill, the increased risk of venous thrombosis has not been eliminated. The risk is affected by patient age, weight, and thrombophilia status. The type of progestin also affects the risk [2-3].

Malignant hypertension ( $\mathrm{MH}$ ) has been described in association with high-dose (50 - $100 \mathrm{mcg}$ ) estrogen OCPs since the publication of Weir et al. in 1971 [4]. Although the rise in blood pressure (BP) is usually mild, some women will have a more significant increase in BP, and hypertensive emergencies may very rarely occur. Development of hypertension is more likely to occur in patients who developed hypertension during a prior pregnancy or who have a family history of hypertension [5]. Although 5\% of women on OCP develop hypertension, the incidence of $\mathrm{MH}$ in this group of patients is unknown. Malignant phase hypertension may occur within weeks of commencing therapy or after several years. Despite the fact that recent preparations contain lower doses of estrogen, there is no room for complacency when giving OCP. Close medical supervision and regular blood pressure measurements during OCP treatment are mandatory. We present a case of $\mathrm{MH}$ developing in a patient within two years of commencing OCP containing low-dose (30 mcg) estrogen.

\section{Case Presentation}

A 21-year-old Caucasian female with a past medical history of fibromyalgia and a family history of hypertension (both grandparents) was admitted with a three-day history of headache and blurring of vision in her left eye. Her BP was 210/150 and physical examination was essentially normal, apart from the visual acuity of 6/4 (right eye) and 6/1 (left eye) with papilledema. Laboratory workup revealed a normal blood count, renal function, liver function, serum angiotensin-converting enzyme (ACE), 24-hour urinary catecholamine/cortisol, chest x-ray, abdominal/renal ultrasound, sestamibi scan, computed tomography (CT) of the head/renal angiogram, and magnetic resonance imaging (MRI) of the aorta/chest/ovaries. The reninaldosterone level was raised with a recumbent aldosterone/renin of $8.5 \mathrm{ng} / \mathrm{dl}$ and $908 \mathrm{ng} / \mathrm{ml} / \mathrm{hr}$, respectively, as well as a standing aldosterone/renin of $19.30 \mathrm{ng} / \mathrm{dl}$ and $1964 \mathrm{ng} / \mathrm{ml} / \mathrm{hour}$ (hr), respectively. An electrocardiogram was significant for left ventricular hypertrophy (LVH) (Figure 1), an echo showed LVH and an ejection fraction of 45\%, and a transesophageal echocardiogram confirmed an incidental leiomyomatous interventricular septum. Her medications, which were continued on admission, included tramadol, $100 \mathrm{mg}$ twice daily (bid), and low-dose estrogen OCP. During the hospital course, Labetalol, $200 \mathrm{mg}$ bid, was started. The $\mathrm{BP}$ remained at $165 / 105 \mathrm{~mm} \mathrm{Hg}$ with a heart rate (HR) of 58 beats per min (bpm). Labetalol was discontinued and Moxonidine, $200 \mathrm{mcg}$, Indapamide, $5 \mathrm{mg}$, and amlodipine, $10 \mathrm{mg}$ (all once daily), were initiated. By hospital day 15 , the BP remained elevated at 170/100 mmHg with $\mathrm{HR}$ at $88 \mathrm{bpm}$. The OCP and amlodipine were stopped and metoprolol, $25 \mathrm{mg}$ bid, was started. By hospital day 32, her BP was 108/60 mmHg. A diagnosis of MH due to OCP was made, and all anti-hypertensive medications were stopped except for the metoprolol. The patient was discharged home on metoprolol with a BP of 107/55 mmHg. On follow-up in the medical clinic three months later, the visual disturbances had completely resolved and her BP was 98/56 mmHg. Repeat renin/aldosterone was normal. Her visual acuity was 6/4 (right) and 6/5 (left). The metoprolol was stopped, and a BP check one year later was 103/58 mmHg. 


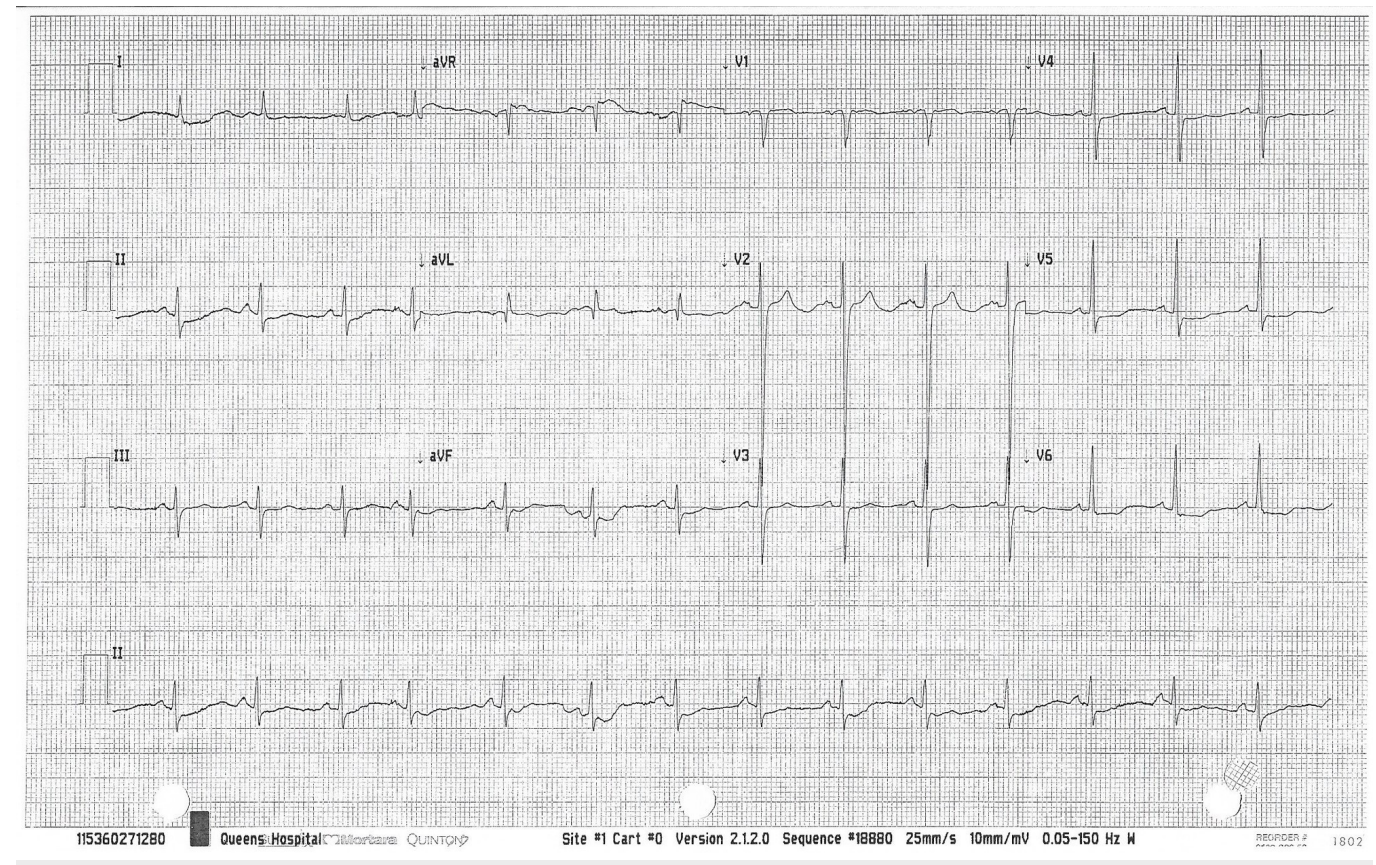

FIGURE 1: Left ventricular hypertrophy

\section{Discussion}

One-third of patients aged 15-44 years old who develop MH are likely to be on high-dose estrogen OCP. As far as we know, our case is the third documented case of MH occurring in a patient on low-dose estrogen OCP. The risk factors for developing MH include the use of highdose estrogen OCP, hypertension in pregnancy and family members, diabetes mellitus, obesity, smoking, alcohol abuse, and age greater than 35 years. Mechanisms of development of $\mathrm{MH}$ include an increased hepatic production of renin substrate, arteriolar fibrinoid necrosis, thrombosis, and renal infarction. The singular most important predictor of resolution of $\mathrm{MH}$ is the presence of renal impairment. Although the presence of LVH suggests long-term hypertension in our patient, the absence of renal impairment suggests an excellent long-term prognosis. $\mathrm{MH}$ can occur within eight weeks to eight years of commencing OCP. The 10-year survival is $90 \%$ if there are no other comorbidities compared with $50 \%$ in patients with renal impairment. In this patient, the MH caused by OCP induced an increase in renin secretion, causing the secondary elevation of aldosterone. Her hypertension was fully resolved within three months of stopping the OCP.

In the review of the literature (Table 1), Harris et al. described a case of MH associated with oral contraceptive therapy. The patient had never been pregnant and had no family history of hypertension. After one year of antihypertensive therapy, the patient developed symptoms of postural hypotension. Therapy was discontinued and the patient's blood pressure subsequently returned to normal [6]. Zacherle et al. described a case with severe hypertension that developed while the patient was on OCP. Antihypertensive agents controlled the blood pressure satisfactorily and the BP remained normal after withdrawal of all therapy. Reintroduction of a sequential oral contraceptive agent three years later again resulted in severe hypertension associated on this occasion with early hypertensive retinopathy and irreversible renal failure [7]. Dunn et al. presented a case of a young lady with a history of hypertension and being overweight who developed $\mathrm{MH}$ after taking oral contraceptive preparations for two years. Control of her BP was obtained by the withdrawal of the oral contraceptive agent and antihypertensive therapy [8]. Weir et al. found the increase in systolic blood pressure to be the same in women taking either low-dose or high-dose estrogen oral contraceptive preparations 


\section{Cureus}

[4]. The mechanisms responsible for the hypertensive effect of oral contraceptives are incompletely understood. Both estrogen and progesterone appear to contribute in a dosedependent fashion. The renin-angiotensin system (RAS) may be involved since estrogen stimulates the hepatic production of renin substrate (angiotensinogen) [9]. Early epidemiologic studies using high-dose estrogen found a mean elevation in BP of 3 to $5 \mathrm{mmHg}$, with approximately $5 \%$ of women developing overt hypertension [10]. A subsequent prospective cohort study of over 68,000 women on lower doses of estrogen demonstrated that, as compared with women who had never used oral contraceptives, the age-adjusted relative risk of developing hypertension was 1.5 for current use and 1.1 for past use [11].

\begin{tabular}{|c|c|c|c|}
\hline $\begin{array}{l}\text { First } \\
\text { Author } \\
\text { (Ref.) }\end{array}$ & Year & Case & Description \\
\hline $\begin{array}{l}\text { Harris } \\
{[6]}\end{array}$ & 1969 & $\begin{array}{l}27-y e a r- \\
\text { old female }\end{array}$ & $\begin{array}{l}\text {-No previous history of HTN or renal disease/No family history of HTN -Taking OCPs for } \\
30 \text { months which led to malignant HTN }(\mathrm{BP}=220 / 150) \text {-Within a month, her BP had } \\
\text { fallen to } 200 / 110 \mathrm{~mm} \mathrm{Hg} \text { after taking antihypertensive medications and stopped taking } \\
\text { OCPs }\end{array}$ \\
\hline $\begin{array}{l}\text { Zacherle } \\
\text { et al. [7] }\end{array}$ & 1972 & $\begin{array}{l}\text { 29-year- } \\
\text { old female }\end{array}$ & $\begin{array}{l}\text {-No previous history of HTN or renal disease/No family history of HTN -First time taking } \\
\text { OCP was in } 1967 \text { and after one year, BP increased to } 220 / 150 \text {, and by stopping OCP } \\
\text { and taking antihypertensive medication, high BP dropped to normal after three months. } \\
\text { Second time taking OCP was in 1970, and after one year, malignant HTN (BP = } \\
\text { 250/190) led to irreversible renal failure }\end{array}$ \\
\hline $\begin{array}{l}\text { Dunn et } \\
\text { al. [8] }\end{array}$ & 1975 & $\begin{array}{l}\text { 26-year- } \\
\text { old female }\end{array}$ & $\begin{array}{l}\text {-History of gestational HTN in } 1960 \text {. Started OCP in } 1964 \text { and got malignant HTN (BP = } \\
\text { 230/150) in } 1966 \text {-High BP was rapidly controlled after discontinuing OCP and taking } \\
\text { antihypertensive medications }\end{array}$ \\
\hline $\begin{array}{l}\text { Weir et } \\
\text { al. [4] }\end{array}$ & $\begin{array}{l}1971- \\
1974\end{array}$ & $\begin{array}{l}\text { A } \\
\text { prospective } \\
\text { study of } 66 \\
\text { women }\end{array}$ & $\begin{array}{l}\text {-High systolic BP after one year (between } 115.1+/-1.3 \text { ), high diastolic BP at the end of } \\
\text { two years -Discontinuance of OCPs resulted in the return of BP to pretreatment levels } \\
\text { within three months -No cases of severe or malignant HTN among patients. }\end{array}$ \\
\hline
\end{tabular}

\section{TABLE 1: Summary of Cases Reviewed in the Literature}

HTN: hypertension; OCPs: oral contraceptive pills; BP: blood pressure.

\section{Conclusions}

The chronic use of oral contraceptives will slightly increase the systemic BP in most women. It is advisable to avoid OCP in high-risk patients and do regular BP checks on patients on OCP. In patients presenting with hypertension or MH while on OCP, the OCP should be discontinued with a follow-up of the BP before an extensive workup is done.

\section{Additional Information}

\section{Disclosures}

Human subjects: Consent was obtained by all participants in this study. Conflicts of interest: In compliance with the ICMJE uniform disclosure form, all authors declare the following: 
Payment/services info: All authors have declared that no financial support was received from any organization for the submitted work. Financial relationships: All authors have declared that they have no financial relationships at present or within the previous three years with any organizations that might have an interest in the submitted work. Other relationships: All authors have declared that there are no other relationships or activities that could appear to have influenced the submitted work.

\section{References}

1. Chasan-Taber L, Stampfer MJ: Epidemiology of oral contraceptives and cardiovascular disease . Ann Intern Med. 1998, 128:467-77. 10.7326/0003-4819-128-6-199803150-00008

2. van Hylckama Vlieg A, Helmerhorst FM, Vandenbroucke JP, et al.: The venous thrombotic risk of oral contraceptives, effects of oestrogen dose and progestogen type: results of the MEGA case-control study. BMJ. 2009, 339:b2921. 10.1136/bmj.b2921

3. Lidegaard Ø, Løkkegaard E, Svendsen AL, Agger C: Hormonal contraception and risk of venous thromboembolism: national follow-up study. BMJ. 2009, 339:b2890. 10.1136/bmj.b2890

4. Weir RJ, Briggs E, Mack A, et al.: Blood-pressure in women after one year or oral contraception. Lancet. 1971, 297:467-71. 10.1016/S0140-6736(71)91087-7

5. Lim KG, Isles CG, Hodsman GP, et al.: Malignant hypertension in women of childbearing age and its relation to the contraceptive pill. Br Med J (Clin Res Ed). 1987, 294:1057-59.

10.1136/bmj.294.6579.1057

6. Harris PW: Malignant hypertension associated with oral contraceptives . Lancet. 1969, 2:46667. 10.1016/S0140-6736(69)90169-X

7. Zacherle BJ, Richardson JA: Irreversible renal failure secondary to hypertension induced by oral contraceptives. Ann Intern Med. 1972, 77:83-85. 10.7326/0003-4819-77-1-83

8. Dunn FG, Jones JV, Fife R: Malignant hypertension associated with use of oral contraceptives . BMJ. 1975, 37:336-38. 10.1136/hrt.37.3.336

9. Effect of Hormonal Contraceptives and Postmenopausal Hormone Therapy on Blood Pressure . (2016). Accessed: July 10, 2017: http://www.uptodate.com/contents/effect-of-hormonalcontraceptives-and-postmenopausal-hormone-therapy-on-blood-pressu....

10. Woods JW: Oral contraceptives and hypertension. Hypertension. 1988, 11:II11-15. 10.1161/01.hyp.11.3_pt_2.ii11

11. Chasan-Taber L, Willett WC, Manson JE, et al.: Prospective study of oral contraceptives and hypertension among women in the United States. Circulation. 1996, 94:483-89.

10.1161/01.CIR.94.3.483 